Article

\title{
Responding to Climate Change in Tropical Countries Emerging from Armed Conflicts: Harnessing Climate Finance, Peacebuilding, and Sustainable Food
}

\author{
Augusto Castro-Nunez \\ International Center for Tropical Agriculture (CIAT), Km 17 recta Cali-Palmira, Cali 763537, Colombia; \\ augusto.castro@cgiar.org
}

Received: 7 August 2018; Accepted: 26 September 2018; Published: 10 October 2018

\begin{abstract}
Linking climate action with sustainable development goals (SDGs) might incentivize social and political support to forest conservation. However, further examination of the conceptual entry points for linking efforts for reducing forest-based emissions with those for delivering SDGs is required. This review paper aims to contribute to fulfilling this research need. It provides insights into the links between conserving forests for climate change mitigation and peacebuilding. Specifically, the paper examines opportunities to harness climate finance for conserving forests and achieving long-lasting peace and sustainable food. It does so via a literature review and the examination of the Orinoquia region of Colombia. The findings from the literature review suggest that harnessing climate finance for conserving forests and peacebuilding is, in theory, viable if the activities are designed in accordance with social, institutional, and economic factors. Meanwhile, the Orinoquia region provides evidence that these two seemingly intractable problems are proposed to be solved together. At a time when efforts for reducing forest-based emissions are being designed and targeted at (post-) conflict areas in Colombia and elsewhere, the paper's findings might demonstrate the compatibility of programs aimed at reducing forest-based emissions with efforts relating to peacebuilding and sustainable food to both environmental and non-environmental government agencies.
\end{abstract}

Keywords: climate finance; REDD+; forest conservation; peacebuilding; sustainable food systems

\section{Introduction}

Whether climate finance can be harnessed to deliver forest conservation and other development priorities of countries experiencing armed conflicts is this paper's overarching research query. This is an important query given that many of the developing countries that are officially disposed toward implementing approaches for reducing forest-based greenhouse gas (GHG) emissions, such as the mechanism for reducing emissions from deforestation and forest degradation (REDD+), are currently experiencing or emerging from armed conflicts [1-3]. Also, it has been recently argued that the long-term success of such approaches will be contingent upon their capacity to mobilize a broad range of stakeholders [4], which in turn depends on their alignment with development priorities. In the case of tropical countries experiencing (or emerging from) armed conflicts, these priorities would be largely related to peacebuilding.

Arguments around the potential of tropical forest landscapes to contribute to climate change mitigation are contested. On the one hand, it is widely recognized that tropical forest ecosystems provide various services that, to varying degrees, contribute to human well-being and climate change mitigation [5-7]. While the fixation and storage of GHGs are important tropical forest environmental services [5], uncertainty is high as to the extent of how changes in forest cover contribute to global GHG emissions [8]. Early estimations indicated that forest cover changes contribute some 
$18-20 \%$ of global GHGs. However, recent studies indicate that these estimates are exaggerated $[9,10]$. Such variations in estimations largely result from the different measurement methods that have been employed. Initial estimates relied on national GHG inventories or on country reports submitted to the United Nations Food and Agriculture Organization (FAO), whereas recent estimates are based on analyses of forest cover changes and the production of above-ground biomass maps (using satellite imagery). Irrespective of the differences of their findings, these studies commonly recognize the biophysical opportunities for tackling climate change arising from forest landscapes [11,12]. However, other studies argue that approaches to reducing forest-based emissions might pose threats to economic growth, local livelihoods, forest governance, biodiversity conservation, and the rights of indigenous peoples and local communities [13-16]. Critics also point to the approaches' low social and political feasibility [17-20], in particular because forest landscapes not only play a key role in climate change mitigation, they also host many of the world's conflicts [21,22]. Moreover, it could be argued that the increasing demand for food and farm land will worsen tropical deforestation, ecosystems degradation, hunger, and civil unrest if action is not taken.

Despite arguments contesting the social and political feasibility of approaches for reducing forest-based emissions, they are a key component of a global strategy to achieve the Paris Agreement's goal of limiting global temperature increases to below 1.5 degrees Celsius relative to pre-industrial conditions. For instance, REDD+ has received much attention from developed and developing countries alike, since it was first debated in global climate talks [23]. Moreover, bilateral and multilateral donors have pledged more than US $\$ 4.7$ billion to support the design and implementation of approaches for reducing forest-based emissions, such as REDD+ and other initiatives for achieving sustainable forest landscapes [24,25]. Accordingly, various developing countries are designing and implementing strategies for reducing deforestation as a means to conserve forest landscapes, mitigate climate change, and access climate finance.

There are several reasons for such levels of support. REDD+ supporters have labeled it as the most cost-effective approach to tackling climate change [26]. Some supporters have also argued about its potential to generate important social and environmental co-benefits (which are referred to as "non-carbon benefits" in global policy discussions) for biodiversity conservation [27]; forest governance [13]; sustainable forest management [28]; and community development [29]. Although the current level of resource commitment is unprecedented, REDD+ has yet to incentivize sufficient national-level decision-making in relation to its aims to reduce forest loss and forest degradation. Furthermore, contrary to expectations, REDD+ action is far from adequate, and has largely been limited to the environmental sector and to those who agree that climate change action is needed. This trend is consistent across a range of climate change mitigation initiatives [30], and is perhaps based on evidence that climate finance would not compete with land-use opportunity costs [14,31-35].

In such contexts, co-benefits could arguably be better linked with sustainable development goals (SDGs) to mobilize a broader range of stakeholders. Recent evidence suggests that the co-benefits derived from climate action provide sufficient incentive to secure support for activities, even from those who reject the dire forecasts of climate change impacts [4]. In that respect, linking climate finance with key SDGs might incentivize political support-beyond just the environmental sector-for climate change mitigation. For instance, both academic and policy discussions are exploring the mutually beneficial interactions between approaches for reducing forest-based emissions and those for peacebuilding [36]. Such co-benefits will be of particular interest to various countries that are designing and implementing strategies for reducing deforestation as a means to conserve forests and access climate finance, and that also experience or are emerging from armed conflicts [37]. Although empirical evidence shows further co-benefits may arise from pursuing forest carbon storage approaches in areas that are considered priorities for peacebuilding [38], further research is required to understand how climate finance might link forest conservation and peacebuilding.

This paper examines opportunities to harness climate finance for conserving forests and achieving long-lasting peace. It does so via a literature review and the examination of a case study. In the 
following section, I provide the conceptual entry points for linking efforts for reducing forest-based emissions with those for delivering peace. I then present and discuss how these two seemingly intractable problems could be solved together and simultaneously support sustainable (low-carbon) food production in the Orinoquia region of Colombia, within an initiative for achieving sustainable forest landscapes that is being implemented and that could be expanded to other regions facing similar challenges around the world. Finally, the paper discusses the findings and concludes with a consideration of the lessons learned emerging from designing landscape approaches in a region that, while emerging from a long period of armed conflict, aspires to become a center of agricultural production. The article draws on the experience of the author in the research, policy (global climatic negotiations), and practitioner aspects of climate finance, forest conservation, and peacebuilding.

\section{Conceptual Entry Points for Linking Climate Finance, Forest Conservation, and Peacebuilding}

\subsection{Peacebuilding}

Recent studies suggest that REDD+ contributions to SDGs may also arise outside the environmental sector, for instance, in considering the mechanism's compatibility with peacebuilding activities [36-38]. However, there could be further examination of the peacebuilding concept and its links with rural development and forest conservation $[39,40]$. Peace research, along with the peacebuilding concept, has its beginning in the mid-20th century when the International Peace Research Institute (PRIO) was launched in Oslo [41,42]. From the very start, peace studies focused on understanding the conditions for peace, ideally, in transdisciplinary (the integration of different academic perspectives) and transnational (the integration of different global, national, regional, and local establishments) manners [41]. It is within this emerging academic discipline that the concept of peacebuilding continues to evolve [43,44]. This discipline emphasizes the importance of addressing the root causes of conflict and differentiates among responses to conflict. As Johan Galtung (1976) [42] argued in his essay, "Three Approaches to Peace: Peacekeeping, Peacemaking, and Peacebuilding", there are different levels at which peace can be established. He argued that short-term measures (i.e., peacekeeping approaches) aim to reduce overt physical violence (usually in the form of armed conflict), whereas longer-term measures (i.e., peacemaking and particularly peacebuilding) aim to address the root causes of conflict, which he terms "structural violence" (e.g., institutions that impede certain social groups' access to services). Galtung argued that achieving sustainable peace requires addressing the structural causes of war and undertaking efforts to support local communities' capacities to manage and overcome conflict. Lederach (1997) expanded this line of thought by arguing that peacebuilding is a dynamic process that goes beyond post-conflict reconstruction and involves several activities that both precede and follow peace agreements. Therefore, violent conflict should be managed at all phases by processes of "conflict transformation", which entails building new relationships, behaviors, attitudes, and structures [45].

Over the years, peace studies have been moving from solely understanding the conditions of the presence (or absence) of violence toward a discipline that also puts forward suggestions on how to build resilient, peaceful environments, for example, by means of "peace education" and "peace action" [41]. This evolution is built on the similarities between peace and development studies. Indeed, peacebuilding approaches resemble development programs in a way that it is difficult to determine which output would be specifically attributable to which objective. Some scientists have even considered them as "two faces of the same coin" [41]. Furthermore, some of the metrics to measure the performance of peacebuilding initiatives are based on development indicators [46-48].

In practice, there are wide-ranging interpretations of what constitutes a "peacebuilding intervention". Definitions range from "support to safety, security, and political processes" to the "provision of basic services and livelihoods" (UN, 2010 [44]). However, the common agreement is that to reduce the risk of a relapse into conflict, interventions should include a relatively narrow set of activities. Even conservation approaches (e.g., those that restrict rural peoples' access to forests) 
could create conditions for further violence if implemented, for example, in contexts where the root causes of conflict are linked to access to land and forest resources [49]. Therefore, in order to reduce the risk of a relapse into conflict, the United Nations recommends that any peacebuilding intervention be designed to achieve the following objectives: address the drivers and root causes of conflict; build institutions and capacities of individuals, communities, and authorities to manage conflict and deliver services; enhance social cohesion and build trust among social groups; and build trust in and the legitimacy of governments.

\subsection{Links between Tropical Forests and Armed Conflicts}

Identifying opportunities for reducing deforestation as a means to access climate finance while simultaneously contributing toward peacebuilding requires understanding the links between tropical forests and armed conflicts. In the tropics, countries with extensive forested areas also often have conflicts, ranging from local-level disputes to armed conflicts [21,22]. Across the globe, disputes have arisen around issues such as land access, resources and property rights, and land-use policies that prioritize particular uses (i.e., legal uses) over others (i.e., illegal uses) [22,50]. Disputes may also arise over conservation priorities. When powerful actors with vested interests intervene in local disputes, they often inflame latent tensions, which may escalate into violence [51]. Different academic disciplines propose a range of causal links between forest cover and armed conflicts, although the majority originates from the "environmental security" field. According to this discipline, natural resources can influence armed conflict through any of three possible mechanisms: scarcity or the unequal sharing of natural resources [52]; accessibility to and competition over natural resources [53]; or opportunities for covert operations of illegal armed groups [54]. Meanwhile, research has found that tropical forest landscapes are often areas (1) where state presence is weak; (2) where disputes over land rights and access to land exist; and (3) that contain high-value natural resources, which can finance combatants and armed groups' hideouts [54-56].

Despite arguments linking forests with armed conflicts, the findings of the empirical research indicate that the mere condition of 'tropical forest cover' is a poor predictor of conflict $[56,57]$. However, empirical analyses might be faulted for their myopic focus on national and sub-national level correlations between tropical forest cover and armed conflicts, without considering other factors contributing to conflict-i.e., these studies often fail to account for the complex interplay of social, economic, and institutional contexts surrounding the existence of valuable resources [57]. As a consequence, limited progress has been made in determining the links between forests and armed conflicts.

\subsection{Causes of Forest Cover Change in The Tropics}

Proposing appropriate strategies to achieve forest conservation, either for biodiversity or for climate change mitigation, requires understanding what causes forest cover changes. Interlinks between the causes of deforestation and forest degradation are complex and at different levels (international, national, and local) [58,59]. Over the last few decades, scientists have sought to elucidate the causes of deforestation using different academic perspectives, methods, and approaches [60,61]. These approaches include meta-analyses of economic models [62] and sub-national case studies [63]. Angelsen and Kaimowitz (1999) [62] consistently concluded that causes of deforestation include: increased roads; raised agricultural prices; decreased wages; and a shortage of off-farm employment. Meanwhile, Geist and Lambin (2002) [63] argued that the influence of complex factors (demographic, economic, technological, cultural, institutional, and political) on agricultural expansion, wood extraction, and infrastructure extension drives deforestation.

Policies influencing forest cover change include those for infrastructure (road construction that increases agricultural and logging revenues and open access for new agricultural colonization), land tenure, and agriculture and food production [64]. Governments usually implement such policies in order to achieve national priorities, such as "economic development" and "food production". 
For instance, the agricultural sectors in developing countries are usually a major contributor to their respective national gross domestic products (GDP), employment levels, and international trade balances. This observation is often used to justify policies promoting the expansion of the agricultural frontier into forestland as a means of increasing agricultural production, ensuring food security, boosting employment, raising incomes, and achieving rural development.

Scientists have applied the (Forest) Environmental Kuznets Curve (EKC), and the Forest Transition Theory (FTT) to identify and analyze the relationships between economic development and deforestation [65-68]. EKC broadly proposes that during the early phases of a country's development, deforestation occurs due to economic growth (i.e., income growth results from the exploitation of forest products and land-use changes for agriculture and food production). It argues that increases in economic indicators accelerate deforestation, but that (at a certain stage of economic expansion), deforestation then decreases. An inverted U-shape depicts this tendency. Some critics of EKC's findings argue that the statistical analyses on which the curve is based are not robust [67]. Meanwhile, FTT states that it is not likely that deforestation will continue over time, as the opportunity costs of deforestation increase in line with forest scarcity [66]. Circumstances that might influence the emergence of forest transitions include forest scarcity, economic development, and rural out-migration [68,69].

While some studies link rural out-migration with forest recovery [70], others identify its counterpart (i.e., rural in-migration) as a major driver of forest cover loss [71-73]. However, other evidence suggests that the impact of out-migration on forest cover depends on numerous factors. It points to the importance of the drivers of migration (e.g., armed conflicts or the scarcity of land for agricultural production), as well as the interplay of evolving characteristics, such as household resettlement, flows of resources, changes in labor availability, and shifts in household composition [74-78].

Other researchers assert that rural in-migration only partially explains deforestation in tropical agricultural frontiers [79]. Others again point to the additional contribution to deforestation of a lack of formal tenure among newly arrived migrants, as farmers clear patches of forests to demonstrate "improvements" to the land so as to enhance their legal claim over it $[69,80]$. Indeed, this pattern continues where farmers then sell their "claimed" land and move further into forested areas to repeat the process $[69,81]$. A common conclusion drawn from this observation is that providing tenure security would reduce deforestation. However, there is not enough evidence to ensure that tenure security will result in forest conservation [82,83]. Moreover, evidence suggests that under certain circumstances (e.g., if investments into forestland conversion is the driver of deforestation), tenure insecurity could protect forest $[62,84]$.

Although the identified causes of deforestation and forest degradation differ, the literature reflects a general consensus on several issues. One is that the causes of deforestation are context-specific and involve processes occurring at multiple scales [60]. Another is that agricultural expansion, globally, is the main direct cause of deforestation [58,79,85-87]. Meanwhile, there is a divergence on the question of whether commercial or subsistence agriculture has a greater impact on forest cover [85]. This debate continues despite the significant reduction in government-led settlement programs, which have facilitated access to new agricultural colonization fronts since the 1970s, at which time industrial agriculture and agricultural supply chains demonstratively became the overwhelming cause of deforestation $[85,87]$.

There is even more divergence in opinion and arguments around the trends of deforestation, in particular the correlation between deforestation and poverty, which are often founded on faulty premises. For instance, the prevailing misconception that clearing forests is inexpensive [88] prompts the assumption that subsistence farmers invest limited resources in clearing great areas of forests as a way out of poverty. Another misconception is that poverty reduction will lead to the reduction of deforestation caused by subsistence agriculture [89]. In contrast, the evidence has indicated links between poverty and reduced rates of forest loss [90]. This may relate in part to the financial and labor requirements for both agricultural production and frontier expansion [62,84]. Moreover, there is an increasing recognition that less intensive subsistence agricultural systems such as slash-and-burn 
agriculture help maintain forest biomass [91], particularly when this provides a period of fallow regrowth to allow forest regeneration [92]. As such, some researchers argue that lands under agricultural systems that include fallow periods in their cycles should not be regarded as deforested, but rather as degraded [92-94]. Another body of research points to clear correlations between deforestation and armed conflicts. For instance, Geist and Lambin (2002) [63] considered the influence of socio-political events, such as war and forced displacements, as an underlying cause of forest cover change. Similarly, some studies have found links between deforestation and corruption, democracy, political instability, and armed conflict [95-97].

There is no clear consensus in the literature as to whether conflict has negative impacts on forest cover or conversely helps to conserve it. Armed conflicts may influence forest cover dynamics through a number of channels [70,98-101]. On the one hand, armed conflicts might lead to forest cover losses in places where armed groups exploit natural resources in order to finance their military campaigns [96]. On the other hand, armed conflicts might result in forest regeneration and reduced deforestation, as armed forces preserve dense forest areas as cover for their operations [76].

In sum, existing studies have provided varied and often divergent findings about the impacts of conflict and post-conflict processes on forest cover. Country-level studies suggest that conflict may contribute to both increases and decreases in forest cover [76]. Some scientists have attributed forest conservation within conflict-affected areas to economic disruption [98,102], forced migration [70], and international remittances [76]. For instance, in Sierra Leone, conflict-affected areas have reportedly experienced less forest loss in comparison to conflict-free areas [98]; in the Democratic Republic of the Congo, conflict has caused increased forest loss and a reduction of economic activities, such as mining [99]. Meanwhile, in El Salvador, international migration influenced by periods of violence (and subsequent remittances) has caused forest recovery. In contrast, in Rwanda, few differences in forest cover net gains were detected between conflict and post-conflict periods. Existing differences appear to be explained by resource exploitation proximity to refugee settlements (forest losses) and forced migrations (forest gains) [100]. Similarly, in Colombia, varied impacts on forest cover have been reported. For instance, in some cases, forced migration has resulted in forest recovery, while in others, it has resulted in further deforestation [103]. Differences may be related to armed groups' economic and conservation policies. For instance, one study related that in one area, a non-legal armed force enforced coca eradication and prevented mining, thereby avoiding deforestation, while in a neighboring area, a different armed group promoted coca cultivation, causing deforestation [104].

Other examples of observed impacts from the ways that armed groups govern forests include increased agricultural coverage (including grassland) and deforestation associated with the presence of paramilitary groups [101], and increased deforestation rates linked to illegal crop cultivation in a demilitarized zone granted by the government of Colombia (GoC) to the Revolutionary Armed Forces of Colombia (FARC) at the end of the 1990s [105]. Such trends in post-conflict settings include the resultant conservation of the demilitarized zone between North and South Korea [102], and the increased forest cover in post-conflict Puerto Rico (i.e., linked to economic development) [106].

\subsection{Economic and Policy Approaches for Tackling Causes of Forest Cover Changes}

During the last few decades, diverse economic and policy instruments aimed at curbing deforestation and forest degradation have been promoted and abandoned at both international and national levels [107]. Despite these interventions, the annual global rate of deforestation remains above 13 million ha [108]. Arguably, mechanisms that have been promoted globally, such as those for biodiversity conservation, respond to global priorities that do not necessarily match developing countries' national or local development priorities. Policies derived from such mechanisms have generally aimed to curb deforestation by promoting legal reforms in the forestry sector [64]. Among the most commonly used mechanisms are: loan conditionality (i.e., providing loans conditional upon legal reforms within the forestry sector); donor coordination (i.e., increasing the effectiveness of official 
development assistance); debt relief (i.e., reducing international debt in exchange for establishing a trust fund to finance conservation initiatives); and demand management (i.e., trade certifications).

At the national scale, the adoption of such policies is usually limited to the environmental sector. Forest conservation is not generally a priority activity for governments, which typically allocate resources to other activities. Policies that have aimed at curbing deforestation include restrictions on land and natural resource use (e.g., delimitation of "natural protected areas") and attempts to increase the value of standing forest through the provision of economic incentives to promote sustainable production alternatives, such as payment for environmental services (PES) schemes [32]. Likewise, concessions (i.e., permits for the sustainable use of forest resources) and decentralization (i.e., the transfer of forest management authority to local governments or communities) are common mechanisms (implemented nationally) to avoid deforestation and forest degradation [28]. Although these policies should address nationally determined causes of deforestation in order to ensure success, they all too often focus on promoting local initiatives that are dependent on donor funding. At the local level, projects to mitigate forest clearance commonly include: sustainable forest management; conservation areas; integrated development and conservation; or capacity building. More recently, these efforts have been expanded to include afforestation, reforestation, and avoided deforestation. However, these initiatives are usually designed to address the direct (and most obvious) causes of deforestation and forest degradation, and do not necessarily consider communities' priorities and preferences [39].

\subsection{The Mechanism for Reducing Forest-Based Emissions}

REDD+ is the latest internationally promoted approach to incentivizing developing countries to implement national policies aimed at reducing forest carbon emissions. It was proposed in the United Nations Framework Convention on Climate Change (UNFCCC) as an alternative to previous approaches tackling the causes of deforestation described above. Discussions around REDD+ started in 2005, during the 11th session of the Conference of the Parties (COP11). Then, Papua New Guinea and Costa Rica jointly proposed options to reduce the GHG emissions caused by deforestation (RED) $[109,110]$. The argument put forward was that neither UNFCCC nor the Kyoto Protocol considered emissions resulting from deforestation in developing countries.

The initial RED proposal constituted the first attempt to include deforestation in tropical countries as part of a global climate agreement. Nonetheless, these proposals neglected the socio-political issues that prevent the successful implementation of clean development mechanisms (CDM) in the forestry sector [19]. Moreover, the proposals failed to recognize that most of the developing countries did not yet have the necessary capacities for monitoring emissions from forest cover changes $[8,111,112]$, nor did they take into account that few tropical forested countries have the requisite social and political stability to implement such initiatives [17,20].

The scope of the initial proposal has increased over time. COP11 delegates viewed forest degradation (which was mainly identified as a result of selective and illegal logging) as an important cause of GHG emissions. The COP, as such, requested the Subsidiary Body for Scientific and Technological Advice (SUBSTA) to undertake the consultations and necessary actions to evaluate REDD feasibility. This has led to the inclusion of forest degradation in the mechanism. The Bali Action Plan that was agreed to at COP13 indicated that approaches to mitigating climate change must include "forest degradation in developing countries and the role of conservation, sustainable forest management and enhancement of carbon stock" [113]. Following the decisions taken at COP15, REDD+ now refers to "policy approaches and positive incentives in issues related to [the] reduction of emission from deforestation and forest degradation; and the role of conservation, sustainable forests management and enhancement of forest carbon stocks in the developing countries" [114]. UNFCCC COPs' successive decisions offer further details on the evolution of the concept from RED to REDD+ [23].

Reaching an agreement on the means of implementing REDD+ was challenging. This arguably relates to the diverse and context-specific causes of tropical deforestation and forest degradation [86], 
operating at different scales [63] and involving a variety of stakeholders and economic agents [28]. Expansions in the mechanism's scope could be interpreted as an attempt to reach mitigation goals without omitting countries with low deforestation but high forest degradation [115]. The mechanism's scope was expanded in COP15 so as to avoid damage to: local livelihoods; indigenous peoples and local communities' rights; biodiversity; forest governance; and economic growth [116].

Policy discussions were primarily linked with concerns related to: the scale of implementation or whether to implement the mechanism at the national and/or sub-national scale [117]; REDD+ economics and expectations of high carbon payments; social and environmental safeguards; and more recently, REDD+ non-carbon benefits. Consensus was expected to be reached at COP15 (held in December 2009 in Copenhagen, Denmark). Instead, decisions about voluntary actions (to be implemented by developing countries and the eligible forestry sectors) were delayed until COP16. Further details about the means through which to implement the mechanism were defined only in the Warsaw framework for REDD+, which was decided at COP19 [118].

For developing countries to achieve the status of being "ready" for REDD+, they must undertake four main actions: (1) establish forest reference emissions levels (FREL); (2) implement systems for measuring, reporting, and verifying (MRV) GHG emissions reductions; (3) design and implement REDD+ national strategies or strategies to combat the causes of deforestation; and (4) implement systems to inform how environmental and social safeguards are considered. Eligible activities include: reducing deforestation emissions; reducing forest degradation emissions; conserving forest carbon stocks; managing forests sustainably; and enhancing forest carbon stocks. Additionally, a COP decision was reached regarding the three phases of REDD+ (readiness, implementation, and result-based payments). Currently, developing countries are designing strategies and implementing pilot projects supported by bilateral and multilateral funds, such as the Forest Carbon Partnership Facility (FCPF), the United Nations REDD initiative (UN-REDD), and the Forest Investment Program (FIP) $[109,119,120]$.

As detailed above, many studies have explored the ways that different groups within climate negotiations conceptualize and negotiate ideas and resources [110,121,122]. However, scholars outside the environmental discipline, such as those from political science and international relations, have not paid enough attention to the topic [109]. This disinterest might signal that REDD+ discourses have not yet extended beyond the environmental sector; it might also indicate that REDD+ will prove nothing more than the most recent "conservation fad" [107,123].

\subsubsection{The REDD+ Rationale}

REDD+ aims to incentivize developing countries to reduce deforestation and conserve their forests in a bid to reduce GHG emissions. Therefore, a key expectation is that the financial benefits resulting from REDD+ activities will outweigh their costs, and that the rent generated will incentivize governments and local communities to maintain them [14]. Such an expectation was mainly built upon land-use opportunity cost models [31,32,35], which generally assume land-use opportunity costs to be the largest and principal cost component. However, what constitutes the total costs of and benefits from REDD+ remains uncertain [34,124,125].

A number of studies that have assessed the benefits and costs of REDD+ demonstrate uncertain or low benefits (Coomes et al., 2008 [126]; Isenberg and Potvin, 2010 [127]), as well as high transaction and implementation costs $[125,126]$. Moreover, evidence indicates that even in the absence of transaction and implementation costs, REDD+ might not compete with high land-use opportunity costs [14,31-33,35]. For instance, a recent study based on six carbon-based Peruvian projects calculated the transaction and implementation costs to be between US $\$ 0.16$ and $1.44 \mathrm{ha}^{-1}$ year $^{-1}$ [125]. Nonetheless, the analysis did not consider that these initiatives ought to build upon long-term conservation efforts. Therefore, the transaction and implementation costs in areas without previous interventions (such as those affected by armed conflicts) may greatly exceed these estimates, thereby limiting the mechanism's efficiency, and therefore its effectiveness. In such scenarios, 
actions should demonstrate that they contribute toward the priorities of respective governments and farmers in order to gain their support and secure subsidies for their implementation.

\subsubsection{Environmental Safeguards and Non-Carbon Benefits}

Beyond expectations of financial revenues, constraints to REDD+ implementation are comparative to those faced by other rural development and conservation efforts $[39,128]$. These constraints include economic dependence on natural and forest resource exploitation; trade-offs between economic growth and environmental objectives; a lack of effective coordination mechanisms for the integration of environmental objectives into non-environmental policy sectors; a lack of capacity to design and implement strategies to combat deforestation; the presence of corruption, illegal activities, and conflicts; and the emergence of undesired social and environmental impacts [17,20,129]. Indeed, the recognized impacts of these listed challenges prompted the need to define environmental and social safeguards [114,130].

Meanwhile, other scholars argued that these challenges should not overshadow the potential for REDD+ to generate SDG co-benefits. Moreover, it has been argued that generating evidence of the co-benefits of addressing climate change could attract funding and increase political and social support [4], particularly among the sectors of society that would not support mitigation actions based purely on anticipated climate change impacts [30]. Furthermore, studies of co-benefits point to the importance of integrating carbon storage actions into sustainable development efforts more broadly, thereby integrating social and environmental goals [130].

In response, evidence of further co-benefits is arising from considering REDD+'s compatibility with peacebuilding activities. However, while a few studies have examined the relationship between forest-based emissions and land-related conflicts, they are dwarfed by the body of research that is focused solely on the link between conflict and unclear "carbon rights" (which are closely linked to unclear land tenure rights) [14,131]. These studies suggest that forest-based mitigation efforts implemented in situations of unresolved land tenure might exacerbate existing tensions [132]. Awareness of these types of conflicts led the UNFCCC to adopt safeguards aimed at preventing conflict and securing the rights of indigenous peoples and local communities [114]. These important safeguards are designed to increase the potential success of forest carbon storage approaches. However, importantly, they do not consider peacebuilding co-benefits that could also arise from REDD+ implementation, and vice versa.

\section{The Case Study}

The opportunities for and barriers to harnessing climate finance to conserve forests and build peace are best understood through ongoing efforts that link a country's climate change policy with its ongoing peace process. We analyze here the case of the Orinoquia (Figure 1), which is a region in Colombia where a program to reduce forest-based emissions and achieve low-carbon agricultural development is being implemented.

\subsection{The Orinoquia Region, Colombia}

Located in eastern Colombia, Orinoquia's vast areas of natural savannas and grasslands extend into the Amazon rainforest. The Orinoquia region of Colombia spans four departments: Arauca, Casanare, Meta, and Vichada. These four departments comprise an area of about 250,000 square kilometers that belong to the Orinoco River watershed, and is home to 1.37 million people, $32 \%$ of whom reside in rural areas. Despite the peace agreement, violence remains there due to the presence of organized crime gangs, which are reportedly made up of ex-paramilitary group members. 


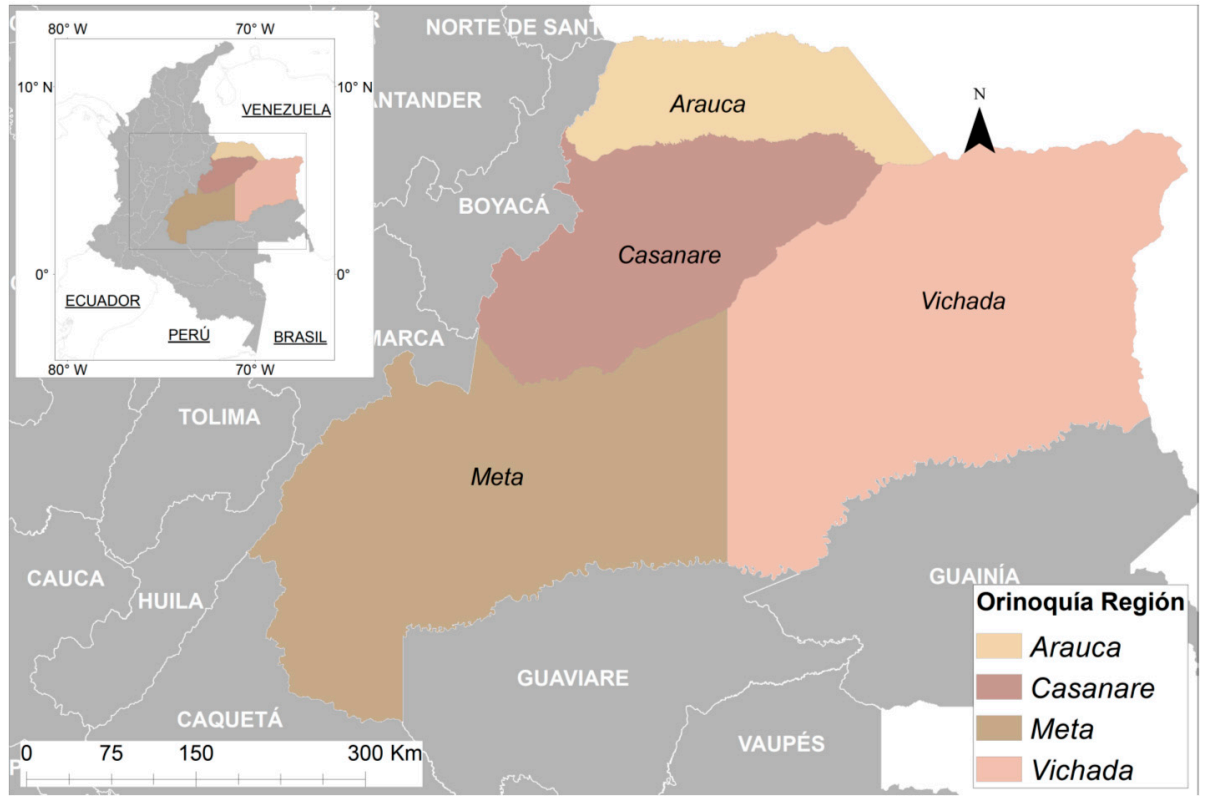

Figure 1. The Orinoquia region, as prioritized by the Colombian government in its efforts to reduce forest-based emissions, addresses the causes of armed conflict, and achieves sustainable food production.

Considered one of the last agricultural frontiers in the world, the agricultural sector significantly contributes to the economy of the region. Consistently, the agriculture, forestry, and other land uses (AFOLU) sector is a major contributor to the region's emissions. The conversion of forest to pasture lands is a main source of region's emissions. As indicated by various studies over time, the expansion of areas for cattle grazing and illicit crop production-mainly in southern areas where savannas meet the Amazon forests-constitutes the main causes of deforestation in the Orinoquia $[103,105,133]$. However, new studies indicate the existence of a strong connection between the armed conflict and deforestation, which are interconnected with coca production, cattle pasture, and land grabbing [37]. The second most important category of emissions relates to enteric fermentation, followed by forest degradation, land conversions to cropland, and nitrous oxide emissions from soil management. Current land-use trends show that oil palm production has had the greatest increase in plantation area. The establishment of forest plantations and cultivation of agricultural commodities (e.g., maize, soybean, forage grasses, and rice) have also taken place, especially in the Altillanura of the Meta and Vichada departments.

Land-use dynamics are expected to change in the Orinoquia, particularly considering the Colombian government's plans to promote agricultural development in the region. Some authors argue that because of the peace agreement, land-use dynamics would exacerbate deforestation and further shrink the area for endangered species in Colombia [134]. Upcoming causes of forest and species loss might include the opening of new deforestation frontiers, new infrastructure investments, and large-scale agricultural development [135]. Conversely, other studies have argued that the peace agreement will create an environment that is conducive to implementing policy measures to counteract threats to Colombian forest landscapes and simultaneously address structural causes of conflict [38].

\subsection{The Orinoquia Sustainable Integrated Landscape Program}

Reducing forest-based emissions is a key component of Colombia's strategy to achieve its Paris Agreement commitments. The Colombian government has committed to reducing $20 \%$ of countrywide emissions (against a business-as-usual level) and to increasing climate ambition if provided with international financial support. It has also committed to reducing the country's deforestation to zero by the year 2020. In that context, Colombia is prioritizing the Orinoquia as a region that can help reduce 
forest-based emissions, achieve sustainable peace, and realize its potential to become a breadbasket for the country and the world.

The World Bank is also looking at the Orinoquia as a region that can help mitigate climate change, address the causes of armed conflict in Colombia, and achieve sustainable food production [136]. The implementation of the first phase of the World Bank-funded Orinoquia Sustainable Integrated Landscape (OSIL) project has started under the leadership of two Colombian agencies, the Ministry of Agriculture and Rural Development (MADR) and the Ministry of Environment and Sustainable Development (MADS). OSIL is part of a broader program funded by the World Bank's BioCarbon Fund Initiative for Sustainable Forest Landscapes (ISFL) [137]. It adopts a two-phase approach.

During the first phase, OSIL will define the strategy to reduce deforestation and achieve payments for emissions reductions in the Orinoquia's AFOLU sector [138] It will also identify how such financing can achieve long-lasting peace and sustainable (and low-carbon) food production [138]. In the subsequent phase, the initiative will establish an emissions reduction program, which will include a performance-based payment mechanism, in order to achieve sustainable (low-carbon) landscape management and promote the adoption of suitable land uses among farmers.

The ISFL will provide results-based finance at the jurisdictional scale based on a comprehensive carbon estimation approach of AFOLU emissions [139]. Accounting for emissions reduction from AFOLU for result-based payments on a jurisdictional scale has yet to be tested in the country or elsewhere. Thus, OSIL's first phase will also put in place a set of tools that are needed to assess the program's performance and ensure the accomplishment of the BioCarbon Fund's requirements relating to landscape carbon accounting and social and environmental safeguards. Among the necessary tools that the initiative will develop include: the AFOLU reference level that will be used as the benchmark to assess the performance of the emissions reduction program (ER program) and make payments; the benefit-sharing mechanism that defines the equitable sharing of the (carbon and non-carbon) benefits deriving from the ER program and its beneficiaries; and the safeguard instruments to mitigate the social and environmental risks and comply with World Bank safeguard policies, land-use strategies, and forest and land management practices.

The first phase of OSIL will also develop and test approaches for sustainable landscape management with a strong focus on reducing deforestation, as well as an emphasis on promoting sustainable (low-carbon) agricultural production systems. Specifically, it will implement activities that are oriented toward creating the enabling environment for the implementation of sustainable landscape management that leads to emissions reductions. These activities include: improving land-use policies; mainstreaming sustainability and climate considerations into land-use planning processes and land title programs that are currently under implementation as part of the peacebuilding agenda; developing and promoting sustainable, low-carbon agricultural production systems; and developing an incentive mechanism to reward communities and other value chain stakeholders for making the transition to zero-deforestation and low-carbon practices.

\section{Discussion and Concluding Remarks}

Since the success of climate change mitigation action is highly dependent on general policy reforms and governance [140], there is a compelling need for it to be linked to broader SDG priorities. Evidence of such links might serve, firstly, to persuade the policymakers and sectors of society that are skeptical of the potential additional benefits of mitigation activities [4,30], and secondly, to mobilize a broader range of stakeholders. In the case of forest-based climate change mitigation, such evidence would also strengthen the argument that while approaches for reducing forest-based emissions are not as cost-effective as initially expected, they are ultimately viable $[125,126]$. Furthermore, these assurances are necessary for maintaining the current political and social support for REDD+ and other climate change mitigation activities. In this way, the evidence of co-benefits serves as something of a self-fulfilling prophecy - that is, sufficient evidence might secure the necessary level of social and political support to make forest conservation viable. Meanwhile, the counter-logic is that, in the 
absence of evidence of co-benefits, political will is liable to fail, as might social support, leading to yet another failed attempt to tackle deforestation and forest degradation [107,123].

Recognizing that REDD+ is at a crossroads where political and public confidence, or lack thereof, may determine its future, this paper investigates the role of climate finance in contributing toward achieving SDGs. Specifically, it examines the opportunities to harness climate finance in order to achieve forest conservation, long-lasting peace, and sustainable food production. This idea is framed in current policy discussions regarding the role of non-carbon benefits to increase political and social support for REDD+. For instance, in the context of limited financial resources to incentivize climate action, I propose that the co-benefits of climate change mitigation could be better exploited to attract funding and increase political and social support, for example, by generating evidence that shows the potential for the integration of forest carbon storage and development priorities.

The findings from the literature review suggest that harnessing climate finance for conserving forests and promoting peace is in theory viable if activities are designed in accordance with social, institutional, and economic factors. Meanwhile, the Orinoquia region of Colombia provides evidence that these two seemingly intractable challenges can be proposed to be solved together. It also offers lessons on how to implement sustainable (and low-carbon) forest landscapes in a region that, while emerging from a long period of armed conflict, aspires to become a center of agricultural production.

First, there are common elements among the strategies that have been implemented to achieve sustainable development, peacebuilding, and forest conservation. Moreover, their objectives are increasingly compatible, and some authors even consider that sustainable development is a prerequisite to peacebuilding and forest conservation [36,39,41]. For instance, rural development objectives include conditions that are conducive to achieving the peacebuilding aims of gaining territorial control and reducing conflict. In that regard, rural development activities apparently contribute toward re-establishing farmers' control over their territories and thus to building peace. This is reflected in the recently signed Colombian peace agreement, where rural development-oriented aspects (including land tenure considerations and agricultural development) were an important part of the negotiation agenda [141]. In turn, evidence suggests that in Colombia, peacebuilding activities enable conditions for and predispose conflict-affected farmers toward forest conservation [36]. Castro-Nunez et al. (2016) [36] found that the impacts of previous conservation and sustainable development programs influence farmers' propensity to conserve forests. The implementation of these programs generally aimed to conserve biodiversity and reduce the causes of conflict. This finding highlights the positive effect of long-term peacebuilding and conservation efforts on farmers' propensity toward forest conservation. This, in turn, suggests that establishing preconditions (i.e., some degree of stability or peace) is an important precursor to undertaking forest-based mitigation projects. Indeed, it implies that these efforts should be jointly designed and appropriately co-delivered. Castro-Nunez et al. (2016) [36] also found that farmers will generally support forest conservation activities, provided that these are compatible with their respective livelihood priorities, including cattle ranching. However, despite this discernible propensity toward conservation, deforestation continues in the studied area. This default to deforestation indicates that conservation efforts will need to be carefully designed in order for them to enhance farmers' livelihood options.

Second, achieving a reduction of forest-based emissions storage in the tropics implies dealing with interconnected issues of deforestation, illegal activities, and armed conflict. In such a case, it requires operationalizing governance models, building capacity, improving infrastructure, implementing land titling programs, facilitating land-use planning, and providing sustainable land uses to move beyond the conflict and contribute toward reducing forest-based emissions. This is particularly true for Orinoquia. The region has just emerged from a 52-year armed conflict, and hosts a significant part of the country's deforestation and conflict-affected areas, where public services and infrastructure remain lacking. In Colombia, there are indeed links between the causes of armed conflict and those of deforestation. Therefore, reducing forest-based emissions requires simultaneously addressing the 
causes of conflict. Recent studies suggest links between conflict and deforestation and access to and control over land [37]. In some areas, cattle ranching may appear to be the cause of deforestation. However, in reality, this is a way to claim ownership of the land, which "owners" intend to sell and thus profit from when the opportunity arises. Within that context, land titling provides a good strategy for linking peacebuilding approaches and REDD+. In fact, evidence suggests that promoting land titling can help preserve both peace and forests, and enhance the quality of life in certain areas. It also suggests, as mentioned above, that the strategies for reducing the causes of the conflict, including but not limited to land titling programs, could facilitate forest conservation, and thus the reduction of forest-related greenhouse gas emissions. However, research findings today only permit partial conclusions to be drawn about the impacts on conservation decisions of land titling programs (these constitute common approaches to reducing forest-based emissions). Instead, the results provide empirical evidence of "preconditions" and other factors that need to be considered alongside common REDD+ approaches.

Third, reducing AFOLU emissions goes beyond providing sustainable land uses and addressing commodity-driven deforestation. It requires developing a sustainable food system. The Colombian government is working to realize the Orinoquia's potential to become a breadbasket for the world, while contributing to climate change mitigation, forest conservation, and peacebuilding. The rationale behind this objective is that feeding the human population has become an increasing developmental challenge. The global population keeps growing, and the demand for food keeps growing with it [142]. There are direct links between agricultural supply chains, and tropical deforestation, which is a major climate change contributor, and experts anticipate that the increasing demand for food and farmland will worsen tropical deforestation, ecosystems degradation, hunger, and armed conflicts, if action is not taken [143]. Within that context, developing sustainable land-use practices is an approach that is commonly used to address both the causes of deforestation and the causes of conflict. Such practices shall ideally be developed in collaboration with stakeholders within agricultural value chains-farmers, governments, technical experts, and buyers, among others-and take into account the needs of and conditions in each region emerging from conflict. For instance, in recent years, companies have been pledging to achieve deforestation-free supply chains as a way to reduce carbon emissions and the loss of biodiversity [144]. This is a trend among hundreds of corporations.

This approach to transform supply chains assumes that companies will not only commit but actually take ambitious actions to reduce deforestation. However, this is uncertain [144]. Companies are first and foremost driven by their bottom lines. If it will mean profit, they will take action. If not, they may commit to taking steps, but not be bold enough to make a difference. Companies may take action, but there is the question of whether this contributes to stopping deforestation. Besides, there is currently no mechanism to monitor and measure that contribution; the proposals disregard that most developing countries do not have the necessary capacities for monitoring land-cover changes $[8,111,112]$. The supply chain approach likewise relies on efforts by companies. However, as mentioned above, combating deforestation requires establishing policies, institutions, infrastructure, and incentives that will facilitate those efforts. Furthermore, it is likely that agricultural supply chains will remain informal in conflict-affected areas. For instance, a number of companies that process milk in the Orinoquia do not pay taxes, and therefore monitoring whether or not they follow sustainable manufacturing practices would be a challenge. Achieving zero deforestation and low-carbon development, as such, means going beyond transforming supply chains. Deforestation will also continue if there is a lack of extension services that support efforts to deter agricultural expansion and curb practices and inputs that increase carbon emissions. Colombia actually has a strategy that incorporates this approach and REDD+, which covers both policies and incentives to lower emissions from deforestation and forest degradation. This suggests the need for a broader approach to zero deforestation and low-carbon development. This involves promoting sustainable agricultural practices, improving land-use policies, and developing a sustainable food system. Sustainable food systems aim to: create environment-friendly supply chains; support value chain actors to meet product quality, safety, and environmental standards; provide incentives that can lead to lower carbon 
emissions within the food system, from production to food waste disposal; and promote responsible food consumption, among other features. Even with concerted efforts by companies, governments, and more, deforestation will continue to happen if the consumption of forest-risk commodities remains at the same level. In order to meet the demand, the same companies may opt to import those commodities, thus exacerbating deforestation across territories.

Fourth, carbon accounting methodologies can be adjusted with the goal of enhancing the potential of climate finance to generate forest conservation, peace, and sustainable food benefits. Improved understanding of the causal links between tropical forest cover and armed conflicts will be needed to this end. There is a common trend that carbon accounting methodologies prioritize intervention in landscapes with historical higher rates of forest-based emissions [145]. This approach underemphasizes the mitigation potential of landscapes with historic low agricultural development, forests at low risk of deforestation, and degraded lands [115]. Similarly, landscapes that used to host armed actions may not benefit from land-based mitigation actions, as they typically have lower historical rates of emissions than their more peaceful counterparts [38]. Reducing deforestation figures prominently as an emissions reduction strategy (REDD+) and as the best bet for fulfilling international commitments to the UNFCCC. REDD+ prioritizes landscapes with higher forest carbon stocks and that simultaneously are at high risk of deforestation. However, each landscape should have the opportunity to develop its strategy based on its own particular conditions. In Colombia, for example, the Amazon region is important for its dense forest cover, yet all of the regions of the country can make contributions toward reducing emissions. Indeed, from a landscape approach perspective, regions with fewer trees (and forests at low historic risk of deforestation and degraded landscapes) are important for taking pressure off forested areas, and may be important for restocking carbon. One such area is the savanna biome of the Orinoquia region, where a diverse landscape constitutes farms, cattle ranches, tree plantations, native savanna, and natural forests. Emissions from the Orinoquia region are comparatively lower than other regions, in part because of the armed conflict. However, with the peace agreement, experts anticipate that conflict would no longer "prevent" investments. Thus, they expect change in the historical trends of key sources of AFOLU emissions and removal. Recent studies have indicated that political stability is attracting greater investors and may lead to increases in economic activities, such as industrial agriculture or livestock, logging, and mining [134,146]. This would particularly happen in areas emerging from armed conflicts. Recent reports confirm this, indicating that land-cover change is sharply increasing in areas previously under FARC control [147]. In addition, uninhabited forests and savannas might provide sites for the relocation of former combatants and displaced farmers [38].

Finally, the paper does not aim to foresee the outcomes of the OSIL initiative, but rather to inform emerging scholarly arguments on the potential of climate finance to bring about improved environmental and peacebuilding outcomes. However, at a time when forest carbon storage is being designed and targeted at (post-) conflict areas in Colombia and elsewhere, they might also demonstrate to government agencies (both environmental and non-environmental) the compatibility of programs aimed at reducing forest-based emissions with efforts relating to peacebuilding, forest conservation, and sustainable food production. As such, further examination of the role of climate finance in linking forest conservation, peacebuilding, and rural development is highly relevant. The imperatives for broad contributions from other academic disciplines ranging from a social-ecological and complex adaptive systems [148-150] to a more peacebuilding-oriented perspective such as the emerging theory of "environmental peacebuilding" [3] stem from the undeniable observation that many of the countries that are implementing strategies to reduce forest-based emissions, including Indonesia, the Democratic Republic of the Congo, Peru, Mexico, and Colombia, host armed conflicts in their forest landscapes [21], thus emphasizing the relevance of the present study and the use of the Orinoquia as a case in point.

Funding: This research was partially funded by the International Climate Initiative (IKI). The Federal Ministry for the Environment, Nature Conservation and nuclear Safety (BMU) supports this initiative on the basis of a decision adopted by the German Bundestag. 
Acknowledgments: The author thanks CIAT's Sustainable Food Systems and Ecosystem Services teams for providing technical and financial support.

Conflicts of Interest: The author declares no conflict of interest

\section{References}

1. Lotta, T.; Peter, W. Armed conflicts, 1946-2012. J. Peace Res. 2013, 50, 509-521.

2. UCDP. PRIO Armed Conflict Dataset v.4-2014. Available online: http://www.pcr.uu.se/research/ucdp/ datasets/ucdp_prio_armed_conflict_dataset/ (accessed on 31 July 2018).

3. Thor, H. Biodiversity conservation and armed conflict: A warfare ecology perspective. Ann. N. Y. Acad. Sci. 2018. [CrossRef]

4. Paul, G.B.; Taciano, L.M.; Yoshihisa, K.; Michał, B.; Guy, D.; Ragna, B.G.; Valdiney, V.G.; Yanjun, G.; Lars-Olof, J.; et al. Co-benefits of addressing climate change can motivate action around the world. Nat. Clim. Chang. 2016, 6, 154-157.

5. Lera, M.; Valerie, K. Reducing greenhouse gas emissions from deforestation and forest degradation: Global land-use implications. Science 2008, 320, 1454-1455.

6. Joyotee, S.; Sara, J.S. Capturing the Value of Forest Carbon for Local Livelihoods. World Dev. 2003, 31, $2143-2160$.

7. Sven, W. Poverty alleviation and tropical forests-What scope for synergies? World Dev. 2001, 29, 1817-1833.

8. Johanne, P.; Navin, R.; Catherine, P. Potvin. Diagnosing the uncertainty and detectability of emission reductions for REDD+ under current capabilities: An example for Panama. Environ. Res. Lett. 2011, 6, 24005.

9. Nancy, L.H.; Sandra, B.; Stephen, C.H.; Sassan, S.S.; Silvia, P.; William, S.; Matthew, C.H.; Peter, V.P.; Alexander, L. Baseline map of carbon emissions from deforestation in tropical regions. Science 2012, 336, 1573-1576.

10. Daniel, J.Z. Carbon from tropical deforestation. Science 2012, 336, 1518-1519.

11. Dixon, R.K.; Solomon, A.M.; Brown, S.; Houghton, R.A.; Trexier, M.C.; Wisniewski, J. Carbon Pools and Flux of Global Forest Ecosystems. Science 1994, 263, 185-190. [CrossRef] [PubMed]

12. Gibbs, H.K.; Brown, S.; Niles, J.O.; Foley, J.A. Monitoring and estimating tropical forest carbon stocks: Making REDD a reality. Environ. Res. Lett. 2007, 2, 45023. [CrossRef]

13. Kanowski, P.J.; McDermott, C.L.; Cashore, B.W. Implementing REDD+: Lessons from analysis of forest governance. Environ. Sci. Policy 2011, 14, 111-117. [CrossRef]

14. Karsenty, A.; Vogel, A.; Castell, F. 'Carbon rights', REDD+ and payments for environmental services. Environ. Sci. Policy 2014, 35, 20-29. [CrossRef]

15. Phelps, J.; Webb, E.L.; Adams, W.M. Biodiversity co-benefits of policies to reduce forest-carbon emissions. Nat. Clim. Chang. 2012, 2, 497-503. [CrossRef]

16. Phelps, J.; Webb, E.L.; Agrawal, A. Does REDD+ Threaten to Recentralize Forest Governance? Science 2010, 328, 312-313. [CrossRef] [PubMed]

17. Karsenty, A.; Ongolo, S. Can 'fragile states' decide to reduce their deforestation? The inappropriate use of the theory of incentives with respect to the REDD mechanism. For. Policy Econ. 2012, 18, 38-45. [CrossRef]

18. Unruh, J.D. Agroforestry, reforestry, and the carbon problem The role of land and tree tenure. Interdiscip. Sci. Rev. 1995, 20, 215-227. [CrossRef]

19. Unruh, J.D. Carbon sequestration in Africa: The land tenure problem. Glob. Environ. Chang. Hum. Policy Dimens. 2008, 18, 700-707. [CrossRef]

20. Unruh, J.D. Tree-Based Carbon Storage in Developing Countries: Neglect of the Social Sciences. Soci. Nat. Resour. 2011, 24, 185-192. [CrossRef]

21. Deanna, D.; Wil, D.J.; Ken-ichi, A. Tropical forests and extreme conflict. Extreme Confl. Trop. For. 2007, 5, 1-15.

22. Gritten, D.; Mola-Yudego, B.; Delgado-Matas, C.; Kortelainen, J. A quantitative review of the representation of forest conflicts across the world: Resource periphery and emerging patterns. For. Policy Econ. 2013, 33, 11-20. [CrossRef]

23. Pistorius, T. From RED to REDD+: The evolution of a forest-based mitigation approach for developing countries. Curr. Opin. Environ. Sustain. 2012, 4, 638-645. [CrossRef]

24. Cerbu, G.A.; Swallow, B.M.; Thompson, D.Y. Locating REDD: A global survey and analysis of REDD readiness and demonstration activities. Environ. Sci. Policy 2011, 14, 168-180. [CrossRef]

25. Streck, C. Financing REDD+: Matching needs and ends. Curr. Opin. Environ. Sustain. 2012, 4, 628-637. [CrossRef] 
26. Stern, N. Stern Review: The Economics of Climate Change; HM Treasury: London, UK, 2006.

27. Bernardo, B.N.; Annabel, K.; Andrew, B.; Richard, G.D.; Holly, K.G.; Andrew, L.; Lera, M.C.; David, L.O.; Jeff, P.; Turner, R.K.; et al. Global congruence of carbon storage and biodiversity in terrestrial ecosystems. Conserv. Lett. 2010, 3, 98-105.

28. Putz, F.E.; Romero, C. Helping curb tropical forest degradation by linking REDD+ with other conservation interventions: A view from the forest. Curr. Opin. Environ. Sustain. 2012, 4, 670-677. [CrossRef]

29. Finn, D.; Margaret, S.; Neil, D.B.; Per, M.J.; Herizo, A.; Bhaskar, K.; Richard, L.; Jon, C.L.; John, M.; Yonika, N.; et al. At the heart of REDD+: A role for local people in monitoring forests? Conserv. Lett. 2011, 4, 158-167.

30. Ana-Maria, B.; Craig, M.; Emma, F.T.; Girish, L.; Mariette, B.; RoseAnne, M. Public division about climate change rooted in conflicting socio-political identities. Nat. Clim. Chang. 2015, 5, 226-229.

31. Bellassen, V.; Gitz, V. Reducing emissions from deforestation and degradation in cameroon-Assessing costs and benefits. Ecol. Econ. 2008, 68, 336-344. [CrossRef]

32. Borner, J.; Wunder, S. Paying for avoided deforestation in the Brazilian Amazon: From cost assessment to scheme design. Int. Rev. 2008, 10, 496-511. [CrossRef]

33. Börner, J.; Wunder, S. The Scope for Reducing Emissions from Forestry and Agriculture in the Brazilian Amazon. Forests 2012, 3, 546-572. [CrossRef]

34. Gregersen, H.; Lakany, H.E.; Karsenty, A.; White, A. Does the Opportunity Cost Approach Indicate the Real Cost of REDD+? Rights and Realities of Paying for REDD+; CIRAD: Washington, DC, USA, 2010.

35. Irawan, S.; Tacconi, L.; Ring, I. Stakeholders' incentives for land-use change and REDD+: The case of Indonesia. Ecol. Econ. 2013, 87, 75-83. [CrossRef]

36. Castro-Nunez, A.; Mertz, O.; Quintero, M. Propensity of farmers to conserve forest within REDD+ projects in areas affected by armed-conflict. For. Policy Econ. 2016, 66, 22-30. [CrossRef]

37. Castro-Nunez, A.; Mertz, O.; Buritica, A.; Sosa, C.C.; Lee, S.T. Land related grievances shape tropical forest-cover in areas affected by armed-conflict. Appl. Geogr. 2017, 85, 39-50. [CrossRef]

38. Castro-Nunez, A.; Mertz, O.; Sosa, C.C. Geographic overlaps between priority areas for forest carbon-storage efforts and those for delivering peacebuilding programs: Implications for policy design. Environ. Res. Lett. 2017, 12, 5. [CrossRef]

39. Blom, B.; Sunderland, T.; Murdiyarso, D. Getting REDD to work locally: Lessons learned from integrated conservation and development projects. Environ. Sci. Policy 2010, 13, 164-172. [CrossRef]

40. Junne, G.; Verkoren, W. Postconflict Development: Meeting New Challenges; Lynne Rienner: Boulder, CO, USA, 2005.

41. Galtung, J. Twenty-Five years of peace research: Ten challenges and some responses. J. Peace Res. 1985, 22, 141-158. [CrossRef]

42. Galtung, J. Three approaches to peace: Peacekeeping, peacemaking, and peacebuilding. In Peace, War and Defense: Essays in Peace Research; Galtung, J., Ed.; Christian Ejlers: Copenhagen, Danmark, 1976; Volume 2, pp. 297-298.

43. Fetherston, A.B. Peacekeeping, conflict resolution and peacebuilding: A reconsideration of theoretical frameworks. Int. Peacekeeping 2000, 7, 190-218. [CrossRef]

44. UN. Peacebuilding and Orientation, 2010. Available online: http://www.un.org/en/peacebuilding/pbso/ pdf/peacebuilding_orientation.pdf (accessed on 31 July 2018).

45. Lederach, J.P. Building Peace: Sustainable Reconciliation in Divided Societies; United States Institute of Peace Press: Washington, DC, USA, 1997.

46. Bush, K. A Measure of Peace: Peace and Conflict Impact Assessment (PCIA) of Development Projects in Conflict Zones; International Development Research Center: Ottawa, ON, Canada, 1998.

47. Lederach, J.P.; Culbertson, H.; Neufeldt, R. Creating indicators. In Reflective Peacebuilding: A Planning, Monitoring and Learning Toolkit; Joan, B., Kroc, I., Eds.; University of Notre Dame, International Peace Studies: Notre Dame, IN, USA, 2007.

48. Zucker, H.; Ahn, R.; Sinclair, S.J.; Blais, M.; Nelson, B.D.; Burke, T.F. Development of a scale to measure individuals' ratings of peace. Confl. Health 2014, 8, 17. [CrossRef] [PubMed]

49. Brottem, L.; Unruh, J. Territorial Tensions: Rainforest Conservation, Postconflict Recovery, and Land Tenure in Liberia. Ann. Assoc. Am. Geogr. 2009, 99, 995-1002. [CrossRef]

50. Peluso, N.L. Rich Forests, Poor People: Resource Control and Resistance in Java; University of California Press: Oakland, CA, USA, 1992. 
51. Kröger, M. Grievances, agency and the absence of conflict: The new Suzano pulp investment in the Eastern Amazon. For. Policy Econ. 2013, 33, 28-35. [CrossRef]

52. Homer-Dixon, T.F. Environmental Scarcities and Violent Conflict: Evidence from Cases. Int. Security 1994, 19, 5-40. [CrossRef]

53. Peluso, N.L.; Watts, M. Violent Environments; Cornell University Press: Ithaca, NY, USA, 2001.

54. Collier, P.; Hoeffler, A. Greed and grievance in civil war. Oxf. Econ. Pap. 2004, 56, 563-595. [CrossRef]

55. Rustad, S.A.; Binningsbo, H.M. A price worth fighting for? Natural resources and conflict recurrence. J. Peace Res. 2012, 49, 531-546. [CrossRef]

56. Rustad, S.C.A.; Rod, J.K.; Larsen, W.; Gleditsch, N.P. Foliage and fighting: Forest resources and the onset, duration, and location of civil war. Polit. Geogr. 2008, 27, 761-782. [CrossRef]

57. Harwell, E. Forests in Fragile and Conflict-Affected States; Program on Forests (PROFOR): Washington, DC, USA, 2010.

58. Peter, H.V.; Neville, C.; Erle, C.E.; Andreas, H.; Patrick, H.; Ole, M.; Harini, N.; Thomas, S.; Karl-Heinz, E.; Nancy, G.; et al. Land system science and sustainable development of the earth system: A global land project perspective. Anthropocene 2015, 12, 29-41.

59. Verburg, P.H.; Erb, K.-H; Mertz, O.; Espindola, G. Land System Science: Between global challenges and local realities. Curr. Opin. Environ. Sustain. 2013, 5, 433-437. [CrossRef] [PubMed]

60. Nicholas, R.M.; Thomas, K.R.; Peter, H.V.; William, J.M.; Ole, M.; Katharina, G.; Andreas, H.; Erle, C.E. Synthesis in land change science: Methodological patterns, challenges, and guidelines. Reg. Environ. Chang. 2015, 15, 211-226.

61. Van Vliet, J.; Nicholas, R.M.; Bianka, B.; Cook, E.; José, M.R.B.; Erle, C.E.; Andreas, H.; Eric, K.; Tien, M.L.; Jianguo, L.; et al. Meta-studies in land use science: Current coverage and prospects. Ambio 2016, 45, 15-28. [CrossRef] [PubMed]

62. Angelsen, A.; Kaimowitz, D. Rethinking the causes of deforestation: Lessons from economic models. World Bank Res. Obs. 1999, 14, 73-98. [CrossRef] [PubMed]

63. Geist, H.J.; Lambin, E.F. Proximate causes and underlying driving forces of tropical deforestation. BioScience 2002, 52, 143. [CrossRef]

64. Pfaff, A.; Sills, E.O.; Amacher, G.S.; Coren, M.J.; Lawlor, K.; Streck, C. Policy Impacts On Deforestation: Lessons Learned From Past Experiences to Inform New Initiatives. Available online: https:/ / nicholasinstitute.duke.edu/ sites/default/files/publications/lessonslearned-paper.pdf (accessed on 27 September 2018).

65. Chiu, Y.-B. Deforestation and the environmental kuznets curve in developing countries: A panel smooth transition regression approach. Can. J. Agric. Econ. Rev. Can. Agroecon. 2012, 60, 177-194. [CrossRef]

66. Culas, R.J. REDD and forest transition: Tunneling through the environmental Kuznets curve. Ecol. Econ. 2012, 79, 44-51. [CrossRef]

67. Stern, D. The rise and fall of the environmental Kuznets curve. World Dev. 2004, 32, 1419-1439. [CrossRef]

68. Thomas, K.R.; Oliver, T.C.; Emilio, M.; Frederic, A.; Arild, A.; Jianchu, X.; Eric, L. Forest transitions: Towards a global understanding of land use change. Glob. Environ. Chang. 2005, 15, 23-31.

69. Rudel, T.; Bates, D.; Machinguiashi, R. A tropical forest transition? Agricultural change, out-migration, and secondary forests in the ecuadorian amazon. Ann. Assoc. Am. Geogr. 2002, 92, 87-102. [CrossRef]

70. Aide, T.M.; Grau, H.R. Globalization, migration, and latin american ecosystems. Science 2004, 305, 1915-1916. [CrossRef] [PubMed]

71. Allen, J.C.; Barnes, D.F. The causes of deforestation in developing countries. Ann. Assoc. Am. Geogr. 1985, 75, $163-184$. [CrossRef]

72. Bilsborrow, R.E. Population-growth, internal migration, and environmental degradation in rural-areas of developing-countries. Eur. J. Popul. Rev. Eur. Demographie 1992, 8, 125-148. [CrossRef]

73. Southgate, D. The causes of land degradation along 'Spontaneously' expanding agricultural frontiers in the third world. Land Econ. 1990, 66, 93-101. [CrossRef]

74. Barbieri, A.F.; Carr, D.L.; Bilsborrow, R.E. Migration within the frontier: The second generation colonization in the Ecuadorian Amazon. Popul. Res. Policy Rev. 2009, 28, 291-320. [CrossRef] [PubMed]

75. Damon, A.L. Agricultural land use and asset accumulation in migrant households: The case of EL salvador. J. Dev. Stud. 2009, 46, 162-189. [CrossRef]

76. Hecht, S.B.; Saatchi, S.S. Globalization and forest resurgence: Changes in forest cover in el salvador. BioScience 2007, 57, 663-672. [CrossRef] 
77. Hecht, S. The new rurality: Globalization, peasants and the paradoxes of landscapes. Land Use Policy 2010, 27, 161-169. [CrossRef]

78. Padoch, C.; Brondizio, E.; Costa, S.; Pinedo-Vasquez, M.; Sears, R.R.; Siqueira, A. Urban forest and rural cities: Multi-sited households, consumption patterns, and forest resources in Amazonia. Ecol. Soc. 2008, 13, 2. [CrossRef]

79. Carr, D.L. Proximate population factors and deforestation in tropical agricultural frontiers. Popul. Environ. 2004, 25, 585-612. [CrossRef] [PubMed]

80. St-Laurent, G.P.; Gélinas, N.; Potvin, C. REDD+ and the agriculture frontier: Understanding colonists' utilization of the land. Land Use Policy 2013, 31, 516-525. [CrossRef]

81. Schelhas, J.; Sánchez-Azofeifa, G.A. Post-Frontier forest change adjacent to Braulio Carrillo National Park, Costa Rica. Hum. Ecol. 2006, 34, 407-431. [CrossRef]

82. Bromley, D.W. Formalising property relations in the developing world: The wrong prescription for the wrong malady. Land Use Policy 2009, 26, 20-27. [CrossRef]

83. Knudsen, C.M.S.; Mertz, O. Improved land tenure not the driver of economic development in a Vietnamese community. Geograf. Tidsskr.-Dan. J. Geogr. 2016, 116, 82-84. [CrossRef]

84. Angelsen, A. Forest Cover Change in Space and Time: Combining The Von Thunen and Forest Transition Theories. In World Bank Policy Research Working Paper 4117; The World Bank: Washington, DC, USA, 2007.

85. Noriko, H.; Martin, H.; Veronique, D.S.; Ruth, S.D.F.; Maria, B.; Louis, V.; Arild, A.; Erika, R. An assessment of deforestation and forest degradation drivers in developing countries. Environ. Res. Lett. 2012, 7, 4009.

86. McCarthy, S.; Tacconi, L. The political economy of tropical deforestation: Assessing models and motives. Environ. Polit. 2011, 20, 115-132. [CrossRef]

87. Rudel, T.K. Changing agents of deforestation: From state-initiated to enterprise driven processes, 1970-2000. Land Use Policy 2007, 24, 35-41. [CrossRef]

88. Van Ausdal, S. Pasture, profit, and power: An environmental history of cattle ranching in Colombia, 1850-1950. Geoforum 2009, 40, 707-719. [CrossRef]

89. Angelsen, A. Agricultural expansion and deforestation: Modelling the impact of population, market forces and property rights. J. Dev. Econ. 1999, 58, 185-218. [CrossRef]

90. Deininger, K.W.; Minten, B. Poverty, policies, and deforestation: The case of Mexico. Econ. Dev. Cult. Chang. 1999, 47, 313-344. [CrossRef]

91. Van Nathalie, V.; Ole, M.; Andreas, H.; Tobias, L.; Unai, P.; Birgit, S.; Cristina, A.; Schmidt-Vogtg, D.; Peter, M.; Stephen, L. Trends, drivers and impacts of changes in swidden cultivation in tropical forest-agriculture frontiers: A global assessment. Glob. Environ. Chang. 2012, 22, 418-429.

92. Mertz, O. Trends in shifting cultivation and the REDD mechanism. Curr. Opin. Environ. Sustain. 2009, 1, 156-160. [CrossRef]

93. Mertz, O.; Mueller, D.; Sikor, T.; Hett, C.; Heinimann, A.; Castella, J.-C.; Guillaume, L.; Casey, M.R.; David, S.R.; Schmidt, D.; et al. The forgotten D: Challenges of addressing forest degradation in complex mosaic landscapes under REDD. Geograf. Tidsskr.-Dan. J. Geogr. 2012, 112, 63-76. [CrossRef]

94. Definitions and Methodological Options to Inventory Emissions from Direct Human-Induced Degradation of Forests and Devegetation of Other Vegetation Types. Available online: https:/ / www.ipcc-nggip.iges.or. jp/public/gpglulucf/gpglulucf_files/Task2/Degradation_cover.pdf (accessed on 31 July 2018).

95. Barbier, E.B.; Damania, R.; Léonard, D. Corruption, trade and resource conversion. J. Environ. Econ. Manag. 2005, 50, 276-299. [CrossRef]

96. Didia, D.O. Democracy, political instability and tropical deforestation. Glob. Environ. Chang. 1997, 7, 63-76. [CrossRef]

97. Sánchez-Cuervo, A.M.; Aide, T.M.; Clark, M.L.; Etter, A. Land Cover change in Colombia: Surprising forest recovery trends between 2001 and 2010. PLoS ONE 2012, 7, e43943. [CrossRef] [PubMed]

98. Burgess, R.; Miguel, E.; Stanton, C. War and deforestation in Sierra Leone. Environ. Res. Lett. 2015, $10,95014$. [CrossRef]

99. Butsic, V.; Baumann, M.; Shortland, A.; Walker, S.; Kuemmerle, T. Conservation and conflict in the Democratic Republic of Congo: The impacts of warfare, mining, and protected areas on deforestation. Biol. Conserv. 2015, 191, 266-273. [CrossRef]

100. Ordway, E.M. Political shifts and changing forests: Effects of armed conflict on forest conservation in Rwanda. Glob. Ecol. Conserv. 2015, 3, 448-460. [CrossRef] 
101. Sanchez-Cuervo, A.M.; Aide, T.M. Consequences of the armed conflict, forced human displacement, and land abandonment on forest cover change in Colombia: A multi-scaled analysis. Ecosystems 2013, 16, 1052-1070. [CrossRef]

102. Kim, K.C. Preserving biodiversity in Korea's demilitarized zone. Science 1997, 278, 242-243. [CrossRef]

103. Sanchez-Cuervo, A.M.; Aide, T.M. Identifying hotspots of deforestation and reforestation in Colombia (2001-2010): Implications for protected areas. Ecosphere 2013, 4, 1-21. [CrossRef]

104. Davalos, L.M.; Bejarano, A.C.; Hall, M.A.; Correa, H.L.; Corthals, A.; Espejo, O.J. Forests and drugs: Coca-Driven deforestation in tropical biodiversity hotspots. Environ. Sci. Technol. 2011, 45, 1219-1227. [CrossRef] [PubMed]

105. Etter, A.; McAlpine, C.; Phinn, S.; Pullar, D.; Possingham, H. Unplanned land clearing of Colombian rainforests: Spreading like disease? Landsc. Urban Plan. 2006, 77, 240-254. [CrossRef]

106. Rudel, T.K.; Perez-Lugo, M.; Zichal, H. When fields revert to forest: Development and spontaneous reforestation in post-war Puerto Rico. Prof. Geogr. 2000, 52, 386-397. [CrossRef]

107. Redford, K.H.; Padoch, C.; Sunderland, T. Fads, funding, and forgetting in three decades of conservation. Conserv. Biol. 2013, 27, 437-438. [CrossRef] [PubMed]

108. FAO. Global Forest Resource Assessment 2010-Key Findings. Available online: http:/ /www.unece.org/ fileadmin/DAM/timber/meetings/20110321/FRA2010_KeyFindings-en.pdf (accessed on 31 July 2018).

109. Corbera, E.; Schroeder, H. Governing and implementing REDD+. Environ. Sci. Policy 2011, 14, 89-99. [CrossRef]

110. Hiraldo, R.; Tanner, T. Forest voices: Competing narratives over REDD+. IDS Bull. 2011, 42, 42-51. [CrossRef]

111. Asner, G.P. Painting the world REDD: Addressing scientific barriers to monitoring emissions from tropical forests. Environ. Res. Lett. 2011, 6, 21002. [CrossRef]

112. Bucki, M.; Cuypers, D.; Mayaux, P.; Achard, F.; Estreguil, C.; Grassi, G. Assessing REDD+ performance of countries with low monitoring capacities: The matrix approach. Environ. Res. Lett. 2012, 7, 14031. [CrossRef]

113. UNFCCC. Report of the Conference of the Parties on Its Thirsteenth Session 2007. Available online: https: / / unfccc.int/resource/docs/2007/cop13/eng/06.pdf (accessed on 31 July 2018).

114. UNFCCC. Report of the Conference of the Parties on Its Sixteenth Session 2011. Available online: https: / / unfccc.int/node/ 6527 (accessed on 31 July 2018).

115. Da Fonseca, G.A.B.; Rodriguez, C.M.; Midgley, G.; Busch, J.; Hannah, L.; Mittermeier, R.A. No forest left behind. PLoS Biol. 2007, 5, e216. [CrossRef] [PubMed]

116. Groom, B.; Palmer, C. REDD+ and rural livelihoods. Biol. Conserv. 2012, 154, 42-52. [CrossRef]

117. Pedroni, L.; Dutschke, M.; Streck, C.; Porr, M.E. Creating incentives for avoiding further deforestation: The nested approach. Clim. Policy 2009, 9, 207-220. [CrossRef]

118. UNFCCC. Report of the Conference of the Parties on Its Nineteenth Session 2014. Available online: https: / / unfccc.int/node/8387 (accessed on 31 July 2018).

119. Atmadja, S.; Verchot, L. A review of the state of research, policies and strategies in addressing leakage from reducing emissions from deforestation and forest degradation (REDD plus). Mitig. Adapt. Strateg. Glob. Chang. 2012, 17, 311-336. [CrossRef]

120. Murdiyarso, D.; Brockhaus, M.; Sunderlin, W.D.; Verchot, L. Some lessons learned from the first generation of REDD+ activities. Curr. Opin. Environ. Sustain. 2012, 4, 678-685. [CrossRef]

121. Humphreys, D. The politics of avoided deforestation: Historical context and contemporary issues. Int. Rev. 2008, 10, 433-442. [CrossRef]

122. Tanner, T.; Allouche, J. Towards a new political economy of climate change and development. IDS Bull. 2011, 42, 1-14. [CrossRef]

123. Fletcher, R.; Dressler, W.; Büscher, B.; Anderson, Z.R. Questioning REDD+ and the future of market-based conservation. Conserv. Biology 2016. [CrossRef] [PubMed]

124. Angelsen, A.; Brockhaus, M.; Sunderlin, W.D.; Verchot, L.V. Analysing REDD+: Challenges and Choices; Center for International Forestry Research (CIFOR) Press: Bogor, Indonesia, 2012.

125. Rendón, O.; Paavola, J.; Healey, J.R.; Jones, J.P.G.; Baker, T.R.; Torres, J. Reducing emissions from deforestation and forest degradation (REDD+): Transaction costs of six peruvian projects. Ecol. Soc. 2013, 18, 17.

126. Coomes, O.T.; Grimard, F.; Potvin, C.; Sima, P. The fate of the tropical forest: Carbon or cattle? Ecol. Econ. 2008, 65, 207-212. [CrossRef] 
127. Isenberg, J.; Potvin, C. Financing REDD in developing countries: A supply and demand analysis. Clim. Policy 2010, 10, 216-231. [CrossRef]

128. Minang, P.A.; Van Noordwijk, M. Design challenges for achieving reduced emissions from deforestation and forest degradation through conservation: Leveraging multiple paradigms at the tropical forest margins. Land Use Policy 2013, 31, 61-70. [CrossRef]

129. Phelps, J.; Friess, D.A.; Webb, E.L. Win-win REDD+ approaches belie carbon-biodiversity trade-offs. Biol. Conserv. 2012, 154, 53-60. [CrossRef]

130. Visseren-Hamakers, I.J.; McDermott, C.; Vijge, M.J.; Cashore, B. Trade-offs, co-benefits and safeguards: Current debates on the breadth of REDD+. Curr. Opin. Environ. Sustain. 2012, 4, 646-653. [CrossRef]

131. Chhatre, A.; Lakhanpal, S.; Larson, A.M.; Nelson, F.; Ojha, H.; Rao, J. Social safeguards and co-benefits in REDD+: A review of the adjacent possible. Curr. Opin. Environ. Sustain. 2012, 4, 654-660. [CrossRef]

132. Saunders, L.S.; Hanbury-Tenison, R.; Swingland, I.R. Social capital from carbon property: Creating equity for indigenous people. Philos. Trans. R. Soc. 2002, 360, 1763-1775. [CrossRef] [PubMed]

133. Armenteras, D.; Cabrera, E.; Rodriguez, N.; Retana, J. National and regional determinants of tropical deforestation in Colombia. Reg. Environ. Chang. 2013, 13, 1181-1193. [CrossRef]

134. Baptiste, B.; Pinedo-Vasquez, M.; Gutierrez-Velez, V.H.; Andrade, G.I.; Vieira, P.; Estupiñán-Suárez, L.M.; Londoño, M.C.; Laurance, W.; Lee, T.M. Greening peace in Colombia. Nat. Ecol. Evol. 2017, 1, 102. [CrossRef] [PubMed]

135. Negret, P.J.; Allan, J.; Braczkowski, A.; Maron, M.; Watson, J.E.M. Need for conservation planning in postconflict Colombia. Conserv. Biol. 2017. [CrossRef]

136. World Bank. Climate-Smart Farming in Colombia's Last Agricultural Frontier. Available online: https:/ / www.worldbank.org/en/news/feature/2018/03/16/el-enfoque-de-la-agricultura-climaticamenteinteligente-la-ultima-frontera-agropecuaria-de-colombia (accessed on 31 July 2018).

137. World Bank. Reducing Carbon Emissions, Let Soil and Trees Do the Dirty Work. Available online: https:/ / www.worldbank.org/en/news/feature/2018/04/24/reducing-carbon-emissions-let-soiland-trees-do-the-dirty-work (accessed on 31 July 2018).

138. World Bank. Sustainable Low-Carbon Development in Orinoquia Region Project. Available online: https:/ / www.worldbank.org/en/news/feature/2018/04/24/reducing-carbon-emissions-let-soiland-trees-do-the-dirty-work (accessed on 31 July 2018).

139. World Bank. ISFL Emission Reductions (ER) Program Requirements. Available online: https:/ / www.biocarbonfund-isfl.org/sites/biocf/files/documents/ISFL\%20ER\%20Program\% 20Requirements\%20Booklet.pdf (accessed on 31 July 2018).

140. Brockhaus, M.; Gregorio, M.D.; Mardiah, S. Governing the design of national REDD+: An analysis of the power of agency. For. Policy Econ. 2014, 49, 23-33. [CrossRef]

141. Republica de Colombia and Fuerzas Armadas Revolucionarias de Colombia. Hacia un Nuevo Campo Colombiano: Reforma Rural Integral. Available online: https:/ /www.mesadeconversaciones.com.co/sites/ default/files/BorradorConjunto-Pol_ticadedesarrolloagrariointegral.pdf (accessed on 31 July 2018).

142. Whitfield, S.; Challinor, A.J.; Rees, R.M. Frontiers in climate smart food systems: Outlining the research space. Front. Sustain. Food Syst. 2018, 2, 2. [CrossRef]

143. Nepstad, D.C.; Boyd, W.; Stickler, C.M.; Bezerra, T.; Azevedo, A.A. Responding to climate change and the global land crisis: REDD+, market transformation and low-emissions rural development. Philos. Trans. $R$. Soc. 2013, 368, 1619. [CrossRef] [PubMed]

144. Lambin, E.F.; Holly, K.G.; Robert, H.; Kimberly, M.C.; Leonardo, C.F.; Rachael, D.G.; De Warous, Y.L.P.; Constance, L.M.; David, M.; Peter, N. The role of supply-chain initiatives in reducing deforestation. Nat. Clim. Chang. 2018, 8, 109-116. [CrossRef]

145. Vergara-Asenjo, G.; Potvin, C. Forest protection and tenure status: The key role of indigenous peoples and protected areas in Panama. Glob. Environ. Chang. 2014, 28, 205-215. [CrossRef] 
146. MADS. Proposed Forest Reference Emission Level for deforestation in the Colombian Amazon Biome for Results-Based Payments for REDD+ under the UNFCCC. Available online: http://unfccc.int/files/land_ use_and_climate_change/redd/application/pdf/frel_amazon_colombia_english_19_12.14_en.pdf (accessed on 31 July 2018).

147. Baena, M.P.; Correa, P. La carretera con la que quieren pavimentar el Amazonas. Available online: http:/ / www.elespectador.com/noticias/medio-ambiente/pavimentando-el-amazonas-articulo-678316 (accessed on 31 July 2018).

148. Carl, F.; Steve, C.; Brian, W.; Marten, S.; Thomas, E.; Lance, G.; Holling, C.S. Regime Shifts, resilience, and biodiversity in ecosystem management. Annu. Rev. Ecol. Evol. Syst. 2004, 35, 557-581.

149. Brondizio, E.S.; Ostrom, E.; Young, O.R. Connectivity and the governance of multilevel social-ecological systems: The role of social capital. Annu. Rev. Environ. Resour. 2009, 34, 253-278. [CrossRef]

150. Eduardo, S.B.; Karen, O.; Xuemei, B.; Frank, B.; Will, S.; Frans, B.; Christophe, C.; Maria, C.L.; Alexander, W.; Jose, P.-O.; et al. Re-conceptualizing the Anthropocene: A call for collaboration. Glob. Environ. Chang. 2016, 39, 318-327.

(C) 2018 by the author. Licensee MDPI, Basel, Switzerland. This article is an open access article distributed under the terms and conditions of the Creative Commons Attribution (CC BY) license (http://creativecommons.org/licenses/by/4.0/). 